\title{
Genetic Transformation of Yeast
}

BioTechniques 30:816-831 (April 2001)

\section{R. Daniel Gietz and Robin A. Woods ${ }^{1}$}

University of Manitoba, Winnipeg, and ${ }^{1}$ University of Winnipeg, Winnipeg, $\mathrm{MB}$, Canada

\begin{abstract}
Genetic transformation was first described by Griffith in 1928 and has since been demonstrated in a variety of organisms, including many species of fungi. This review focuses on the history and technology of the transformation of Saccharomyces cerevisiae. The application of protocols developed for $\mathrm{S}$. cerevisiae to other important yeast species is discussed. The protocols for transformation by spheroplasting, LiAc/ ssDNA/PEG, and electroporation are com pared, and possible mechanisms for transformation are discussed.
\end{abstract}

\section{INTRODUCTION}

The term "transformation" was first used by Griffith (50) to describe heritable changes in certain characteristics of Pneumococcus and is now used to describe DNA uptake in both prokaryotes and eukaryotes, as detected by consequent changes in phenotype. In his extensive and elegant study, Griffith (50) showed that a non-reverting avirulent form of Pneumococcus that lacked a polysaccharide capsule could be "transformed" to a virulent form by injecting heat-killed encapsulated virulent bacteria along with the non-virulent inoculum into the peritoneal cavity of a mouse. He suggested that the "transforming principle" might be a component of the polysaccharide capsule.

In a landmark study, the transforming factor was purified and found to be DNA by Avery, McLeod, and McCarty (3). After its initial description, DNA transformation was attempted for various organisms. These included a number of different yeasts $(73,92)$, Neurospora crassa (84), and Drosophila melanogaster (38). However, until molecular cloning became available to provide evidence of DNA transfer, there were skeptics (53). The ability to clone eukaryotic DNA fragments in E. coli $(20,71,87)$ was an important milestone in the development of transformation protocols for all organisms. The development of molecular genetics in all experimental systems, from bacteria to mammals, has been catalyzed by the ability to induce DNA uptake and subsequent expression in living cells.

Genetic transformation of Saccharomyces cerevisiae, was first reported by Oppenoorth (92) in 1960; however, other workers were unable to repeat his results (53). Khan and Sen (73) carried out an extensive study of DNA transformation of various genetic markers with a number of different yeast species. Their procedure was to grow yeast cultures in the presence of DNA extracted from various yeast strains and then to screen for colonies with a transformed phenotype. They investigated the effects of DNA concentration and the age of cells for best transformation. Their studies furnished convincing evidence for the transformation of yeast but failed to stimulate much interest in the phenomenon.

In 1989, Fincham (37) published a comprehensive review of fungal transformation, which discussed transformation technology and mechanisms of plasmid integration and expression to that date. This review focuses on the development and improvements to the various techniques employed to achieve genetic transformation of yeast.

\section{THE SPHEROPLAST METHOD}

The removal of the yeast cell wall by enyzmatic treatment to yield protoplasts was first reported by Eddy and Williamson (35) in 1957, based on the observation by Giaja that the "the gut juice of the snail Helix pomatia dissolves the cell wall of whole yeasts". Protoplasts, produced by the treatment of yeast cells with snail enzyme, regenerated when embedded in medium containing $30 \%$ gelatin (113) or $2 \%$ agar (112). Hutchison and Hartwell (60) noted that treatment of yeast cells with Glusulase (commercial snail enzyme) did not remove the cell wall completely and suggested that cells produced in this way be termed "spheroplasts". In 1974, Kao and Michayluk (68) showed that polyethylene glycol (PEG) stimulated 
the fusion of plant protoplasts. van Solingen and van der Plaat (117) used PEG plus $\mathrm{CaCl}_{2}$ treatment to fuse yeast spheroplasts derived from strains of the same mating type but with complementary nutritional requirements. This experimental procedure resulted in the exchange of genetic information in yeast by a nonsexual process and could be considered analogous to the soon-to-bediscovered process of transformation.

In 1977, Ratzkin and Carbon (98) reported the isolation of specific hybrid plasmids, constructed from an E. coli plasmid and fragments of yeast DNA, which complemented the hisB and $l e u B$ mutations in $E$. coli. The first successful protocol for the genetic transformation of $S$. cerevisiae, developed by Hinnen et al. (58), had its origins in the investigation of yeast spheroplasts (60) and spheroplast fusion (117). They used the pYEleu10 plasmid (98) containing the LEU2 gene to transform a yeast leu2 3-112 mutant to prototrophy. They removed the yeast cell wall enzymatically and stabilized the resulting spheroplasts with $1.0 \mathrm{M}$ sorbitol before treating them with PEG and plasmid DNA. The treated yeast cells were then suspended in regeneration agar and plated onto medium to select for $L E U+$ cells. More than 100 putative transformants were then analyzed by Southern blot analysis using the E. coli plasmid sequence as a probe. Three types of transformants were identified. In type I transformants, the plasmid DNA was integrated adjacent to the leu 2 locus. In type II transformants, the plasmid had integrated at other locations in the yeast genome. Type III transformants did not contain any bacterial DNA sequences. The authors conclude that the type III transformants were most likely due to replacement of the leu2 3-112 allele with the LEU2 sequence from the transforming plasmid. The transformation efficiency was in the range of $30-50$ transformants $/ \mu \mathrm{g}$ plasmid DNA. Because this plasmid did not contain a yeast replicon, integration was required for the transformants to be stable.

Five months later, Beggs (11) reported the transformation of yeast with an autonomously replicating plasmid. She constructed chimeric plasmids by inserting the endogenous autonomously replicating yeast $2-\mu \mathrm{m}$ circle into the bacteri- al plasmid pMB9. These chimeric plasmids were then used to construct a yeast DNA library. Two plasmids from this library, pJDB248 and pJBD219, proved to complement the leuB mutation in $E$. coli. These plasmids were then used to transform a yeast strain containing the leu2-3 mutant allele utilizing essentially the same protocol as that reported by Hinnen et al. (58). The LEU+ transformants occurred at a frequency of $10^{-5}$ to $10^{-3}$ and an efficiency of $1 \times 10^{4}$ transformants $\mu \mathrm{g}$ plasmid DNA. Southern blot analysis was used to confirm the presence of plasmid sequences, verifying that DNA uptake and genetic transformation had occurred. Finally, the plasmids were recovered from the transformed yeast cells by transformation back into $E$. coli and were shown to have a structure similar to the original plasmid construct.

\section{Plasmid Vector Development}

Three additional types of chimeric plasmid vectors were developed by Struhl et al. (111): (i) YIp (yeast integrating plasmids), which are unable to replicate and transform by integration into the genome of the recipient strain; (ii) YEp (yeast episomal plasmids), which carry the replication origin of the yeast $2-\mu \mathrm{m}$ circle, an endogenous yeast plasmid, and can replicate in the recipient cell; and (iii) YRp (yeast replicating plasmids), which can replicate utilizing yeast autonomous replicating sequences (ARS). These authors showed that integrating vectors transformed with low efficiencies, 1-10 transformants/ $\mu \mathrm{g}$. Plasmids that could replicate in the yeast cell transformed with much higher efficiencies. The YEp vectors transformed with an efficiency of $0.5-2.0 \times$ $10^{4}$ transformants $/ \mu \mathrm{g}$ input plasmid DNA, and the YRp7 plasmid produced $0.5-2.0 \times 10^{3}$ transformants/ $\mu \mathrm{g}$ input plasmid DNA. Struhl et al. (111) demonstrated that plasmids that require integration into the genome transform less efficiently than those yeast plasmid vectors that can replicate autonomously in the yeast cell. Since then, two other yeast plasmid vectors have been developed. Yeast centromere plasmids (YCp) that carry an ARS and a yeast centromere $(25,93)$ are more stable than YRp plasmids but are present in only one copy per cell. Yeast artificial chromosomes (YACs) are propagated as a circular plasmid with a centromere and an ARS plus two selectable markers, two telomeres, and a cloning site $(17,88)$. The vector is linearized by the removal of a sequence between the telomeres, and foreign DNA is inserted into the cloning site. The result is a linear artificial chromosome, 100-1000 $\mathrm{kb}$ in length, that can be propagated through mitosis and meiosis.

\section{Further Development of the Spheroplast Method}

The spheroplasting method of transformation quickly became the gold standard for $S$. cerevisiae. However, Harashima (52) suggested that transformation or DNA uptake was associated with fusion of protoplasts generating polyploid cells during the process. Burgers and Percival (16) showed that cell fusion could be avoided by careful control of the spheroplasting and transformation conditions. They reported transformation efficiencies ranging from 0.4 to $3.0 \times 10^{7}$ transformants $/ \mu \mathrm{g}$ input DNA, with ssDNA being 2- to 5fold more efficient. This is the highest published transformation efficiency using this method, possibly due to the addition of calf thymus or E. coli carrier DNA to the transformation mixture, which may act to protect the plasmid DNA from nucleases (16).

An interesting technique for transforming yeast cells by fusing them with bacterial minicells was published by Gyuris and Duda (51). Bacterial minicells containing plasmid DNA were converted to protoplasts with lysozyme, mixed with yeast cell protoplasts, and treated with PEG to promote cell fusion. This procedure resulted in up to $10^{7}$ transformants/ $\mu \mathrm{g}$ plasmid DNA compared to $7 \times 10^{3}$ transformants $/ \mu \mathrm{g}$ DNA in a control experiment using the spheroplast protocol.

Johnston et al. (65) showed that the spheroplast transformation efficiency displayed by any one strain was a complex genetic trait in $S$. cerevisiae. Crosses between strains that showed high and low transformation efficiencies suggested that the high-efficiency phenotype was inherited as a recessive polygenic trait. In addition, these 
authors showed that incubation of spheroplasts with PEG and DNA at $4^{\circ} \mathrm{C}$ increased transformation efficiency approximately 5-fold for some strains. Increased transformation efficiency in response to a cold shock has also been noted by Broach et al. (12).

Although the spheroplast protocol has been used extensively, it suffers from the drawback that the transformed cells must be suspended and plated in regeneration agar. This means that the transformants cannot be replica plated easily and must be picked individually from the layer of regeneration agar. Substitution of agar by calcium alginate, which dries to form a very thin layer but allows cell wall regeneration (19), allows sampling by replica plating. With the development of other methods of transformation, the spheroplasting method is now mainly used for transformation of YACs (17). A protocol for spheroplast transformation described by Spencer et al. (110) is shown in Table 1.

\section{INTACT YEAST CELL TRANSFORMATION}

Kimura et al. (74) first reported the transformation of intact yeast cells in 1981. Cells were apparently transformed with plasmid vectors after treatment with Triton ${ }^{\circledR}$ X-100; unfortunately, no experimental details or data were given, and we have been unable to find further information on this work. Two years later, Iimura et al. (62) showed that intact yeast cells could be induced to take up the plasmid YRp7 by treatment with a $200 \mathrm{mM} \mathrm{CaCl}_{2}$ solution. Transformants were recovered by plating onto directly selective medium. The transformation efficiency was between 50 and 200 transformants $/ \mu \mathrm{g}$ plasmid DNA. Interestingly, these authors reported that treatment with PEG and $\mathrm{CaCl}_{2}$ did not increase the yield of transformants.

\section{$\mathrm{Li}^{+}$Transformation}

In 1983, Ito et al. (63) published the next innovation in intact yeast cell transformation. They showed that specific monovalent alkali cations $\left(\mathrm{Na}^{+}\right.$, $\mathrm{K}^{+}, \mathrm{Rb}^{+}, \mathrm{Cs}^{+}$, and $\mathrm{Li}^{+}$) could be used in combination with PEG to stimulate plasmid DNA uptake by intact yeast

Table 1. Spheroplast Transformation Protocol

1. Cells are grown in $50 \mathrm{~mL}$ YPAD to a density of $3 \times 10^{7}$ cells $/ \mathrm{mL}$.

2. The cells are harvested by centrifugation at $400-600 \times g$ for $5 \mathrm{~min}$, washed twice in $20 \mathrm{~mL}$ sterile water, and washed once in $20 \mathrm{~mL} 1 \mathrm{M}$ sorbitol. The cells are resuspend in $20 \mathrm{~mL}$ SPEM ( $1 \mathrm{M}$ sorbitol, $10 \mathrm{mM}$ sodium phosphate, $\mathrm{pH}$ 7.5, 10 mM EDTA plus $40 \mu \mathrm{L} \beta$-mercaptoethanol added immediately before use).

3. The cells are converted to spheroplasts by the addition of $45 \mu \mathrm{L}$ zymolyase $20 \mathrm{~T}(10 \mu \mathrm{g} / \mathrm{mL})$ and incubation at $30^{\circ} \mathrm{C}$ for $20-30 \mathrm{~min}$ with gentle shaking. By this time, $90 \%$ of the cells should be converted to spheroplasts.

4. The spheroplasts are harvested by centrifugation at $250 \times g$ for $4 \mathrm{~min}$, and the supernatant is removed carefully. The pellet is washed once in $20 \mathrm{~mL} \mathrm{STC} \mathrm{(1} \mathrm{M}$ sorbitol, $10 \mathrm{mM}$ Tris- $\mathrm{HCl}, \mathrm{pH} 7.5,10 \mathrm{mM} \mathrm{CaCl}_{2}$ ) and resuspended in $2 \mathrm{~mL} \mathrm{STC.}$

5. Spheroplasts are transformed by gently mixing $150 \mu \mathrm{L}$ of the suspension in STC with $5 \mu \mathrm{g}$ carrier DNA and up to $5 \mu \mathrm{g}$ plasmid DNA in less than $10 \mu \mathrm{L}$. The mixture is incubated for 10 min at room temperature. One milliliter of PEG reagent [10 mM Tris-HCl, pH 7.5, $10 \mathrm{mM} \mathrm{CaCl}_{2}, 20 \%$ (w/v) PEG 8000; filter sterile] is added and mixed gently, and incubation is continued for another $10 \mathrm{~min}$.

6 . The spheroplasts are harvested by centrifugation for $4 \mathrm{~min}$ at $250 \times g$ and resuspended in $150 \mu \mathrm{L}$ SOS $\left(1.0 \mathrm{M}\right.$ sorbitol, $6.5 \mathrm{mM} \mathrm{CaCl}_{2}, 0.25 \%$ yeast extract, $0.5 \%$ bactopeptone). Dilutions of spheroplasts are mixed with $8 \mathrm{~mL}$ TOP (selective medium containing $1.0 \mathrm{M}$ sorbitol and $2.5 \%$ agar kept at $45^{\circ} \mathrm{C}$ ) onto the appropriate selective medium containing $0.9 \mathrm{M}$ sorbitol and $3 \%$ glucose. Transformants can be recovered after incubation for $3-4$ days at $30^{\circ} \mathrm{C}$.

cells. Cells were pretreated in $100 \mathrm{mM}$ cation solution followed by the addition of plasmid DNA and PEG (MW 4000) to a final concentration of $35 \%(\mathrm{w} / \mathrm{v})$ and then incubated for $1 \mathrm{~h}$ at $30^{\circ} \mathrm{C}$. This was followed by a 5-min heat shock at $42^{\circ} \mathrm{C}$, after which the cells plated directly onto selective medium. The authors optimized cation concentration, treatment time, cell concentration, and DNA concentration and showed that both PEG and heat shock were essential for transformation. The best results were obtained with $\mathrm{Li}$ acetate ( $\mathrm{LiAc})$. The yields of transformants, 450 transformants $/ \mu \mathrm{g}$ plasmid DNA, were lower that those obtained with contemporary spheroplasting procedures, but $\mathrm{Li}^{+}$ transformation was faster, simpler, and easier. A major advantage was that treated cells did not have to be plated in regeneration agar and could be sampled by replica plating. For these reasons, most laboratories working with yeast readily adopted $\mathrm{Li}^{+}$transformation.

\section{Further Development of the $\mathrm{Li}^{+}$ Transformation Method}

Later in 1983, Ito et al. (64) reported several modifications to their original protocol. The transformation efficiency was increased to 1300 transformants/ $\mu \mathrm{g}$ plasmid DNA if cells were treated for $1 \mathrm{~h}$ in the presence of 2-mercaptoethanol and then subjected to the original transformation protocol utilizing $\mathrm{LiCl}$ but omitting the heat shock. Dithiothreitol (DTT), L-cysteine, and reduced glutathione did not stimulate transformation in a fashion similar to 2mercaptoethanol, but PEG was essential. In the same year, Klebe et al. (75) showed that PEG alone could be used to induce DNA uptake by both $E$. coli and yeast cells. Yeast cells that had been frozen and thawed were incubated with plasmid DNA and PEG1000 for 1 $\mathrm{h}$ at $30^{\circ} \mathrm{C}$. The highest transformation efficiencies obtained were 150 transformants $/ \mu \mathrm{g}$, only $1.5 \%$ of those obtained by spheroplasting. Yamakawa et al. (119) also showed that PEG, in the absence of LiAc, could stimulate transformants. The transformation efficiency was only about a third of that seen when LiAc and PEG were used in combination. They also showed that transformation by this method varies from strain to strain, suggesting that the ability to transform by this method has a genetic component.

Over the next few years, a number of authors published variations on the 
intact yeast cell transformation method. Bruschi et al. (14) also showed that $\mathrm{Ca}^{2+}$ ions could be used in place of $\mathrm{Li}^{+}$ ions and that strains varied in their responses to different cations. They suggested that PEG was responsible for the adsorption of the DNA to the yeast cell. Keszenman-Pereyra and Hieda (72) published a colony procedure for LiAc transformation; however, the transformation frequency was only about 1000 transformants/ $\mu \mathrm{g}$ plasmid DNA with fresh colonies and lower with stored colonies. These authors also showed that single-stranded vector DNA did not transform as effectively as doublestranded vector DNA.

By 1987, the protocol for transform ing intact yeast cells was standardized to include PEG, LiAc, and a heat shock. The addition of sonicated carrier DNA to the transformation increased the efficiency to $2 \times 10^{4}$ transformants/ $\mu \mathrm{g}$ plasmid DNA $(44,103)$. In 1989, Schiestl

\section{Table 2. LiAc/ssDNA/PEG Protocol}

1. Cells are grown overnight in $2 \times$ YPAD, resuspended at $5 \times 10^{6}$ cells $/ \mathrm{mL}$ in warm $2 \times$ YPAD and regrown for two cell divisions to $2 \times 10^{7}$ cells $/ \mathrm{mL}$.

2. The cells are harvested by centrifugation at $3000 \times g$ for $5 \mathrm{~min}$, washed twice in sterile distilled water, and resuspended in sterile distilled water at $10^{9}$ cells $/ \mathrm{mL}$.

3. Samples of $10^{8}$ cells are transferred to $1.5 \mathrm{~mL}$ microcentrifuge tubes, the cells are pelleted, and the supernatant are discarded.

4. The pellets are resuspended in $360 \mu \mathrm{L}$ transformation mixture [ $240 \mu \mathrm{L} 50 \%$ PEG $3500(\mathrm{w} / \mathrm{v}), 36 \mu \mathrm{L} 1.0 \mathrm{M} \mathrm{LiAc}, 50 \mu \mathrm{L} 2.0 \mathrm{mg} / \mathrm{mL}$ single-stranded carrier DNA, $0.1-10 \mu \mathrm{g}$ plasmid DNA plus water to $34 \mu \mathrm{L}$ ].

5. The cells in transformation mixture are incubated at $42^{\circ} \mathrm{C}$ for $40 \mathrm{~min}$. The cells are pelleted in a microcentrifuge, and the transformation mixture is removed.

6. The cell pellet is gently resuspended in $1 \mathrm{~mL}$ sterile water, and samples are plated onto selective medium.

and Gietz (106) showed that the addition of single-stranded carrier DNA or RNA to the transformation reaction stimulated the production of transformants to reach $2 \times 10^{4}$ transformants $/ \mu \mathrm{g}$ plasmid DNA/108 cells. Further studies (42) showed that this procedure was efficient enough to clone yeast genes, including $R A D 4$, which is toxic in E. coli, directly from a library ligation reaction. If two vectors carrying different selectable markers were used in the transformation 
mixture, co-transformation occurred in $30 \%-40 \%$ of the cells selected for one of these genes. The high frequency of co-transformation could be utilized to knock out two different genes in a single transformation reaction or look for nonselective gene disruption using co-transformation with a selective plasmid (42).

Gietz et al. (41) reported that reducing the time that cells were incubated in TE/LiAc buffer improved the transformation efficiency to $1.0 \times 10^{6}$ transformants $/ \mu \mathrm{g}$ plasmid DNA/10 8 cells. Omission of TE from the transformation buffer (46) and optimization of the cell number and carrier and plasmid DNA concentration in the transformation mixture (43) all added to the efficiency and reproducibility of this technique such that one can expect up to $5 \times$ $10^{6}$ transformants/ $\mu \mathrm{g}$ plasmid DNA/ $10^{8}$ cells with most strains (107). The LiAc/ssDNA/PEG protocol can also be carried out in microplates (47), allow ing the simultaneous transformation of multiple strains or colonies. However, a microplate centrifuge is required, and a multichannel pipettor and a 96-prong replicator allow for greater efficiency.

The most recent and efficient version of the LiAc/ssDNA/PEG protocol (118) is shown in Table 2. This protocol should work well for most laboratory strains and is suitable for high-efficiency transformation of plasmid libraries for applications such as the yeast twohybrid system (45).

A number of modifications of the original LiAc/ssDNA/PEG procedure have been published; some are specific for certain growth conditions, and others report an increase in the yields of transformants. For example, several groups report that adding DMSO (10\%) to the transformation mixture increases yield $(6,57)$. Similar improvements in the yield of transformants have been noted if ethanol is added to cells either before or during transformation (78). Soni et al. (109) characterized the effect that adding DMSO or ethanol or both to a transformation reaction utilizing both the rapid and high-efficiency protocols. They found that the increase in transformation efficiency was dependent on the transformation protocol and the specific strain of yeast. The most effective com bination gave 50-fold increases in the yield of transformants. The strain-spe- cific effects of ethanol and DMSO were not additive, and both reduced the viability of yeast cells.

Rapid transformation procedures have been published by Baker (4), Chen et al. (22), Schiestl et al. (107), Gietz and Woods $(46,47)$, and Woods and Gietz (118). In Baker's protocol (4), the yeast cells are scraped from a plate and then treated with the LiAc, PEG, and double-stranded carrier DNA to give a transformation efficiency of $1.1 \times 10^{4}$ transformants/ $\mu \mathrm{g}$ DNA. Freshly grown cells work best; however, four-week-old cultures also gave transformants, albeit at a greatly reduced frequency. Chen et al. (22) showed that cells in stationary phase treated with a "one-step" buffer containing LiAc, PEG, DTT, singlestranded carrier DNA, and plasmid DNA transformed at an efficiency of 2.1 $\times 10^{4}$ transformants $\mu \mathrm{g}$ plasmid DNA. Reddy and Maley (101) also included DTT in their transformation mixture and showed that, in combination with $\mathrm{Ca}^{2+}$, it increased the yield of transformants about 30 -fold to $2.0 \times 10^{4}$ transformants $/ \mu \mathrm{g}$ DNA. The protocols from our laboratory $(46,47,107,118)$ are all based on the LiAc/ssDNA/PEG procedure and yield up to $1 \times 10^{5}$ transformants $/ \mu \mathrm{g}$ plasmid DNA with good transforming laboratory strains. Extension of the heat shock at $42^{\circ} \mathrm{C}$ up to $3 \mathrm{~h}$ increases the yield of transformants 10 fold in some strains (118). A modification of this approach for transforming many different strains at once with a single plasmid was developed by Elble (36). Essentially, the cells are resuspended in LiAc, PEG, and carrier DNA and left overnight at room temperature, and the transformed cells are then plated directly from this mixture onto selective media. The transformation levels range from $2.4 \times 10^{4}$ transformants for cells grown in culture to only 960 transformants $\mu \mathrm{g}$ DNA when cells were harvested from a plate. This technique was also shown to work for Schizosaccharomyces pombe transformation giving rise to $2 \times 10^{4}$ transformants when liquid cultures were used and 208 transformants with a plate-grown cell sample.

Dohmen et al. (34) have developed a method for production of transformation competent frozen yeast cells that yields from 0.2 to $1.0 \times 10^{5}$ transformants $\mu \mathrm{g}$ DNA. The procedure is also applicable to Schwanniomyces occidentalis, $S$. pombe, Kluyveromyces lactis, and Hansenula polymorpha, with transformation efficiencies between 50 and 1000 transformants $/ \mu \mathrm{g}$, depending on the plasmid and yeast species. Tan et al. (114) also published a method for the production of frozen yeast cells that can be used for transformation. The yield was about 1000 transformants/ $\mu \mathrm{g}$ plasmid DNA when a single plasmid was used and about 150 transformants $/ \mu \mathrm{g}$ when two plasmids were used. Both methods are good for producing competent yeast cells ahead of time and then doing transformations at a moment's notice.

In 1991, Moerschell et al. (85) described an LiAc transformation protocol for in vivo mutagenesis with synthetic oligonucleotides. Modifications of this technique $(80,120)$ have im proved the yields of transformants to give 50 transformants $/ \mu \mathrm{g}$ when $100 \mu \mathrm{g}$ oligonucleotide were used in the transformation mixture.

\section{Transformation by Electroporation}

Electroporation was first used by Neumann et al. (90) to induce DNA uptake and transformation in mouse cells. It is now widely used for the transformation of animal cells $(23,55,96)$ and plant cells (8) and is the standard procedure for transforming bacteria in many laboratories $(18,83)$. It is believed that the electric pulse results in the formation of transient pores in the cell membrane, allowing the entry of macromolecules (95). Electroporation was first applied to yeast spheroplasts by Karube et al. (69) and to intact yeast cells by Hashimoto et al. (54). Simpler protocols for the electroporation of intact yeast cells were subsequently reported by Delorme (33) and Simon and McEntee (108). Delorme (33) resuspended log phase cells in fresh medium and electroporated 0.1 $\mu \mathrm{g}$ plasmid DNA using $2.25 \mathrm{kV} / \mathrm{cm}$ and $25 \mu \mathrm{F}$; Simon and McEntee (108) resuspended washed late log phase cells in $0.5 \mathrm{mM}$ Na phosphate buffer containing $10 \%$ glycerol and electroporated using $2.7 \mathrm{kV} / \mathrm{cm}$ and $10 \mu \mathrm{F}$. Both techniques produced $1-4.5 \times 10^{3}$ transformants $/ \mu \mathrm{g}$ plasmid DNA. Rech et al. (100) reported that both circular and linear yeast artificial chromosomes could be electroporated into yeast cells with an 


1. Cells are grown in YPD to a density of $1 \times 10^{7} \mathrm{cells} / \mathrm{mL}$.
2. The cells are harvested by centrifugation ( $1500 \times \mathrm{g}$ for $5 \mathrm{~min}$ ), resuspended at
$1 \times 10^{9} \mathrm{cells} / \mathrm{mL}$ in $25 \mathrm{mM}$ DTT (made in YPD medium, $20 \mathrm{mM} \mathrm{HEPES,} \mathrm{pH}$
8.0 ) and incubated for 10 min at $30^{\circ} \mathrm{C}$.
3. The cells are then washed twice with $\mathrm{EB}(10 \mathrm{mM}$ Tris- $\mathrm{HCl}, \mathrm{pH} 7.5,270 \mathrm{mM}$
sucrose, $1 \mathrm{mM} \mathrm{MgCl}$ ) and resuspended at $1 \times 10^{9} \mathrm{cells} / \mathrm{mL}$ in EB.
4. Samples of $48 \mu \mathrm{L}$ are mixed with $2 \mu \mathrm{L}$ plasmid DNA and delivered between
the electrodes of a square pulse generator $\mathrm{CNRS}$ cell electropulsator.
5. The cells are pulsed with a field strength of $1.74 \mathrm{kV} / \mathrm{cm}$ and a pulse length of
15 ms.
6. One milliliter of prewarmed $30^{\circ} \mathrm{C}$ YPD is added immediately, and the suspen-
sion is incubated for $1 \mathrm{~h}$ at $30^{\circ} \mathrm{C}$. The cells are then pelleted in a microcen-
trifuge resuspended in SD medium and plated onto the appropriate medium
and incubated.

efficiency level of up to 325 transformants $/ \mu \mathrm{g}$. They used a modification of the Hashimoto et al. (54) procedure, which included PEG in the electroporation buffer. The PEG electroporation protocol can be applied to integrative transformation, giving a transformation efficiency of up to $1.8 \times 10^{3}$ transformants $/ \mu \mathrm{g}$ (56). Becker and Guarente (10) reported that cells electroporated in $1.0 \mathrm{M}$ sorbitol at $7.5 \mathrm{kV} / \mathrm{cm}$ and a $25 \mu \mathrm{F}$ capacitance with a $200 \Omega$ resistance in parallel with the sample and then plated onto selective medium containing $1.0 \mathrm{M}$ sorbitol gave transformation efficiencies greater that $3.0 \times 10^{5}$ transformants $/ \mu \mathrm{g}$ plasmid DNA. In 1992, Grey and Brendel (49) reported a rapid colony procedure for electroporation. Yeast cells were scraped from plates and electroporated in HEPES buffer with up to $1 \mu \mathrm{g}$ DNA using a Gene Pulser ${ }^{\mathrm{TM}}$ (Bio-Rad Laboratories, Hercules, CA, USA) with $1.4 \mathrm{kV}, 25 \mu \mathrm{F}$, and $200 \Omega$ in a $0.2-\mathrm{cm}$ gap electroporation cuvette. Transformation efficiencies ranged from 2 to $8 \times$ $10^{3}$ transformants $/ \mu \mathrm{g}$.

Meilhoc et al. (82) reported that electroporation of yeast could be achieved utilizing a square pulse generator CNRS cell electropulsator (JOUAN-France) with a field strength of $1.74 \mathrm{kV} / \mathrm{cm}$. The cell suspension is introduced between two parallel stainless steel flat electrodes $0.5 \mathrm{~cm}$ in width and $0.3 \mathrm{~cm}$ apart in a petri dish $(39,40)$. They also showed that replicating cells in early or mid log phase are transformed 10 times more efficiently than stationary cells using this method. In addition, incubating yeast cells in $25 \mathrm{mM}$ DTT for $10 \mathrm{~min}$ increased the electroporation efficiency up to 5-fold. This procedure can also be applied to frozen yeast cells with highly efficient results.

Manivasakam and Schiestl (81) reported that a hybrid technique using elements of both the LiAc/ssDNA/PEG and electroporation protocols that resulted in $5.2 \times 10^{6}$ transformants $/ \mu \mathrm{g}$ plasmid DNA. Yeast cells were grown overnight to a density of $1-2 \times 10^{8}$ cells $/ \mathrm{mL}$ and resuspended in a $100-\mu \mathrm{L}$ volume containing $1.0 \times 10^{10}$ cells. The cells were then incubated with $20 \mu \mathrm{g}$ ssDNA, PEG, and plasmid DNA at $42^{\circ} \mathrm{C}$ for $15 \mathrm{~min}$. The cells were electroporated in a $0.2-\mathrm{cm}$ cuvette using a Gene Pulser set at $1.5 \mathrm{kV}, 25 \mu \mathrm{F}$, with a pulse controller at $200 \Omega$, diluted in ice-cold YPAD, and plated. The best efficiencies were obtained with 34-170 ng plasmid DNA. However, transformation efficiency decreased with higher plasmid DNA concentrations.

More recently, Thompson et al. (115) reported that yeast cells pretreated in a LiAc/DTT/TE buffer, washed and then electroporated in $1.0 \mathrm{M}$ sorbitol, gave transformation efficiencies of $0.5-1.4 \times 10^{6}$ transformants $/ \mu \mathrm{g}$ plasmid DNA. This pretreatment increased the yield of transformants 15- to 300fold for strains that were refractory to conventional electroporation. The conditions for electroporation were $1.5 \mathrm{kV}$, $25 \mu \mathrm{F}$, and $200 \Omega$ with the Gene Pulser.

Electroporation has also been used to introduce oligonucleotides into yeast using both the exponential (120) and 
Table 4. Advantages and Disadvantages of Transformation Methods

\begin{tabular}{|c|c|c|}
\hline Technique & Advantages & Disadvantages \\
\hline Spheroplasting & $\begin{array}{l}\text { - Efficient transformation of large DNA } \\
\text { constructs such as YACs } \\
\text { - No special equipment needed } \\
\text { - Low cost }\end{array}$ & $\begin{array}{l}\text { - Difficult to optimize } \\
\text { - Cells must be grown overnight. } \\
\text { - Lengthy protocol } \\
\text { - Cell must be plated on osmotically } \\
\text { neutral supportive medium. } \\
\text { - Strain specific variation in transformation } \\
\text { efficiencies }\end{array}$ \\
\hline LiAc/ssDNA/PEG & $\begin{array}{l}\text { - Most efficient procedure (except for } \\
\text { large DNA constructs) } \\
\text { - No special equipment needed } \\
\text { - Simple protocol } \\
\text { - Easily optimized } \\
\text { - Frozen cells can be used. } \\
\text { - Low cost }\end{array}$ & $\begin{array}{l}\text { - Cells must be grown overnight } \\
\text { (unless frozen cells available). } \\
\text { - Strain specific variation in transformation } \\
\text { efficiencies }\end{array}$ \\
\hline Electroporation & $\begin{array}{l}\text { - Efficient procedure (except for large } \\
\text { DNA constructs) } \\
\text { - Short protocol } \\
\text { - Easily optimized } \\
\text { - Frozen cells can be used. }\end{array}$ & $\begin{array}{l}\text { - Substantial setup cost } \\
\text { - Cells must be grown overnight } \\
\text { (unless frozen cells available). } \\
\text { - Strain specific variation in transformation } \\
\text { efficiencies }\end{array}$ \\
\hline Glass Bead method & $\begin{array}{l}\text { - Simple protocol } \\
\text { - Low cost }\end{array}$ & $\begin{array}{l}\text { - Low efficiency transformation } \\
\text { - Cells need osmotic support. }\end{array}$ \\
\hline Biolistic transformation & $\begin{array}{l}\text { - Relatively efficient transformation } \\
\text { - Mitochondria can be transformed. }\end{array}$ & $\begin{array}{l}\text { - High setup cost } \\
\text { - Difficult to determine efficiency } \\
\text { - Preparation of projectiles necessary }\end{array}$ \\
\hline
\end{tabular}

square wave formats (5). Square wave electroporation gave an optimal efficiency of 80 transformants $/ \mu \mathrm{g}$ oligonucleotide. The low efficiency of this type of transformation may in part be due to the requirement for replacement of the chromosomal sequence by that of the oligonucleotide. Yamamoto et al. (120) reported that oligonucleotide transformation in a rad52 strain was more efficient than transformation with linearized integrating plasmid and suggested that the mechanism of transformation by oligonucleotides differs from that of dsDNA.

Electroporation protocols require the delivery of an electric pulse to cells, either in an electroporation cuvette $(10,49,56,81,100,108,115)$ or between electrodes in a petri dish $(39,40,82)$. The parameters of the electroporation: field strength $(\mathrm{kV} / \mathrm{cm})$, capacitance $(\mu \mathrm{F})$, and resistance $(\Omega)$, are different in each protocol, as are the specifics of the preparation of cells, and it is clear that there is considerable variation in the yield of transformants between yeast strains. For any given yeast strain, it may be necessary to investigate the parameters of the pulse and the treatment of cells to obtain a sufficient number of transformants. Electroporation takes less time than either LiAc/ssDNA/PEG or spheroplast transformation, but the initial cost is higher. An efficient electroporation protocol (82) is shown in Table 3.

\section{Transformation Using Glass Beads}

In 1988, Costanzo and Fox (27) reported transformation of yeast cells by agitation with glass beads in the presence of carrier and plasmid DNA. The best transformation efficiency, approximately 300 transformants $/ \mu \mathrm{g}$, was obtained when $2 \mathrm{~mL}$ cells were harvested in late log phase, washed twice and resuspended in 1/10 volume of selective medium containing 1.0 M sorbitol. Carrier DNA, $50 \mu \mathrm{g}$ dissolved in selective medium containing $1.0 \mathrm{M}$ sorbitol, and $5 \mu \mathrm{g}$ plasmid DNA were added to the cell suspension. Sterile glass beads $(0.3$ g; 0.45-0.52 $\mathrm{mm}$ diameter) were added, and the mixture was vortex mixed at top speed for 15-45 s. The supernatant containing the cells was plated onto selective medium containing 1.0 M sorbitol.
The authors note that no transformants are recovered in the absence of sorbitol in the plating medium and suggest that all transformants are derived from the small fraction of cells that are too badly damaged to survive unless osmotically stabilized by sorbitol. This method rivals electroporation for being the least time consuming but is also one of the least efficient of those in current use.

\section{Biolistic Transformation of Yeast}

The biolistic method of transformation was first developed for plant cells (77) and was successfully applied to yeast in 1988 (66). The yeast cells are plated onto the selective medium and then bombarded with $0.5 \mu \mathrm{m}$ gold or tungsten DNA-coated projectiles using compressed helium (2). The plates are then incubated at $30^{\circ} \mathrm{C}$ to allow the growth of transformants. A single bom bardment usually gives rise to a plate confluent with transformants (67). This translates to a transformation efficiency of $10^{4}$ to $10^{5}$ transformants $/ \mu \mathrm{g}$ plasmid DNA. Transformation of mitochondrial markers can be accomplished with pro- 
jectiles coated with mitochondrial genes at $0.1 \%$ of the rate of nuclear transformation. This is the only protocol that can accomplish transformation for yeast mitochondrial genes. The physical nature of this technique is not dependent on cellular characteristics (composition of the cell wall and membrane), and strains or species of yeast that are refractory to conventional techniques should yield transformants with this method. A commercial unit is available from Bio-Rad Laboratories.

\section{TRANSFORMATION OF OTHER YEAST SPECIES}

Transformation protocols have been developed for numerous other species of yeast of genetic or commercial importance. The following list is not exhaustive but will give readers a starting place to identify protocols for their specific needs.

\section{S. pombe}

Shortly after the discovery of spheroplast transformation in $S$. cerevisiae $(11,58)$, this technique was applied to $S$. pombe (9). A protocol for this method, which yields $1-5 \times 10^{4}$ transformants/ $\mu \mathrm{g}$ plasmid DNA, is given by Moreno et al. (86). Variants of this technique can be found on both the Forsberg laboratory Web site (pingu.salk.edu/ forsberg/ tfmn.html) and the Fission Yeast Handbook from the Nurse Laboratory (www. bio.uva.nl/pombe/handbook/section2/ section2-2.html). Protocols for the transformation of intact cells using $\mathrm{Li}^{+}$have also been developed. In 1987, Broker (13) characterized a number of variables and was able to generate $4-9 \times 10^{3}$ transformants/ $\mu$ g plasmid DNA. Okazaki et al. (91) published a method that im proved the transformation efficiency up to $2 \times 10^{6}$ transformants/ $\mu$ g. Current protocols for the LiAc procedure can also be found at the Web sites listed above and in a recent paper by Chua et al. (24). Finally, Hood and Stachow (59) and Prentice (97) have published protocols for the electroporation of $S$. pombe. Transformation efficiencies ranged from $1 \times 10^{3}$ to $2 \times 10^{5}$ transformants $/ \mu \mathrm{g}$ DNA. Protocols for electroporation can also be found at the Web sites listed.

\section{Candida albicans}

The transformation of this yeast can be accomplished using the LiAc or electroporation methods. Sanglard et al. (105) published a method that yields 50-100 transformants $/ \mu \mathrm{g}$ linear plasmid DNA. Thompson et al. (115) found that pretreating cells with LiAc and DTT increased electroporation efficiencies 3- to 5-fold. De Backer et al. (31) published an electroporation protocol that yielded up to 300 transformants $/ \mu \mathrm{g}$ integrating plasmid and 4500 transformants/ $\mu$ g Candida ARS (CARS)-containing plasmid. Other species of Candida can be transformed with modifications of the LiAc protocol (70).

\section{Pichia pastoris}

This methylotrophic yeast is currently being used to produce recombinant proteins. Specific expression vectors, containing the methanol-responsive promoter of the alcohol oxidase gene, give very high levels of recombinant proteins $(28,104)$. Both the spheroplasting and electroporation methods can be used to transform this species. Methods for the transformation of this yeast species can be found in Cregg et al. (28) (spheroplasting), Rosenfeld (104) (electroporation), and Cregg and Russell (29) (both). In addition, a manual for spheroplast transformation can be found at the Invitrogen Web site (http://www.invitrogen.com/ pdf_manuals/pichspher_man.pdf).

\section{Other Yeast Species}

The spheroplast, lithium cation, and electroporation transformation methods have been successfully applied to a number of different yeast species. These include Hansenula polymorpha $(34,48,102,116)$, Klyveromyces spp $(7$, 30,34,61), Yamadazyma ohmeri (94), Yarrowia lipolytica (21), and Schwanniomyces occidentalis $(26,34,76)$.

\section{MECHANISMS OF TRANSFORMATION}

The mechanisms by which DNA is transported into the cell, moves to the nucleus, and becomes established are 
currently unknown. In the spheroplast method, the cell wall, which is presumed to act as a barrier to DNA, is removed before the cells are incubated with PEG and DNA. PEG has been shown to deposit plasmid and carrier DNA onto yeast cells (43). PEG treatment of spheroplasts probably results in the deposition of plasmid and carrier DNA onto the spheroplast surface. The mechanisms by which the plasmid DNA traverses the cell membrane and is transported to the nucleus and established have not been studied.

In the LiAc method, the cell wall is present and will act as a barrier to DNA. De Nobel and Barnett (32) consider the yeast cell wall to act as an ion exchanger. Gietz et al. (43) have proposed that the yeast cell wall binds ds and ssDNA molecules. They suggest that in the absence of carrier DNA most plasmid molecules are bound to the cell wall, making them unavailable for up- take and transformation. The addition of carrier DNA, ds or ss, saturates the cell wall DNA binding sites and increases the probability of plasmid DNA uptake. They propose that singlestranded carrier DNA gives higher yields of transformants because it does not compete with the double-stranded plasmid DNA for uptake and binds more effectively to the cell wall. This is consistent with the observation of Burgers and Percival (16) that singlestranded vector DNA transforms 2-fold more efficiently than the dsDNA using the spheroplasting technique, whereas single-stranded vectors transform 1000-fold less efficiently with the LiAc/ssDNA/PEG method $(43,72)$.

Treatment of yeast cells with LiAc and $\beta$-mercaptoethanol has been shown to increase their permeability (15). Others have shown that the addition of DMSO $(6,57,109)$ or ethanol $(78,109)$ or DTT $(22,101)$ increases transforma- tion efficiency. We suggest that these treatments increase the permeability of the cell wall, in a manner analogous to the effects of an electric pulse (40), and may also affect the physiological properties of the cell membrane, in consequence increasing the uptake of plasmid DNA into the cytoplasm.

The yield of transformants obtained with cells grown to stationary phase (and beyond) can be increased to more than $1 \times 10^{6} / \mu \mathrm{g}$ plasmid $/ 10^{8}$ cells by extending the duration of the incubation at $42^{\circ} \mathrm{C}(118)$. This suggests that the effects of incubation at $42^{\circ} \mathrm{C}$ are not related to the heat shock response (79) but rather that PEG acts as a solvent and extracts a component or components of the yeast cell wall. We suspect that DMSO and ethanol added to the transformation mixture increase this activity.

Recent studies have shown that plasmid topology has a significant effect on transformation efficiency. Raymond et 
al. (99) constructed a plasmid with a 40-bp direct repeat on either side of a NotI restriction site and compared the results of transforming yeast with various topologies of this plasmid. Their results clearly showed that linear plasmids with terminal direct repeats transformed 2.5- to 5-fold more efficiently than either a circular plasmid with direct repeats, a linear plasmid with internal direct repeats, or a linear plasmid with a single terminal copy of the repeat sequence. This increase was obtained with both the electroporation protocol of Meilhoc et al. (82) and the LiAc/ssDNA/PEG protocol (1). These results suggest that linear DNA molecules are taken up more efficiently than circular molecules but that they require re-cirularization by homologous recombination or illegitimate end joining for transformation. Further research will be required to elucidate the specific details of transformation in yeast.

Interestingly, more studies have been devoted to the mechanism of transformation by electroporation in yeast than to either spheroplasting or the LiAc procedure. Ganeva et al. (39) have shown that the primary effect of the electric pulse is to induce transient changes in the cell envelope that allows macromolecules to enter and become trapped in the cell envelope. They found that a fluoresceinated dextran (FD70) became bound within the cell envelope after an EP pulse or treatment of cells with DTT. The pulse also affects the membrane, as evidenced by increased cytoplasmic accumulation of propidium iodide. Permeabilization to propidium iodide was accompanied by loss of viability, but a fraction of the permeabilized cells remained viable. These experiments did not involve transformation with DNA, but the results suggest that the viable permeabilized cells would be transformable. Subsequently, Ganeva et al. (40) carried out an analogous set of experiments with plasmid DNA. They showed that addition of DNase 2-3 s before EP completely prevented transformation; DNase added immediately after EP also reduced transformation, whereas, if the enzyme was added more that $7 \mathrm{~s}$ after EP, the yield was not affected. They proposed that transformation by electroporation involves the following series of events: (i) DNA in the transformation mixture accumulates on the cell surface, (ii) an electric pulse induces transient alterations in the cell envelope that allow insertion of plasmid DNA into the envelope and, perhaps, into the membrane, and (iii) removal of the field results in transfer of the DNA molecules across the membrane into the cytoplasm. They note that the movement of DNA across the envelope and the membrane is "mediated by the yeast cell" and is not the result of electrophoresis or free diffusion. Another model is presented by Neumann et al. (89). In a highly technical paper, these authors hypothesize from kinetic data that DNA uptake is a coupling of DNA binding and electrodiffusive penetration into the cell membrane. The DNA is then translocated across the membrane and binds to a cellular component, which then is the starting point for the transformation process. Further investigation is necessary to identify the cell components taking part in this process.

\section{CONCLUDING REMARKS}

The transformation techniques discussed in this review allow the recovery of up to $2.2 \times 10^{7}$ transformants $/ \mu \mathrm{g}$ plasmid DNA (46). Each technique has advantages and disadvantages (Table 4), and the one best suited for a particular study will depend on the specific needs and resources of the individual researcher.

We have noted that little is known about the mechanisms of transformation in yeast. At the high efficiencies, it is only possible to recover about $5 \%$ transformed yeast cells. What are the specific qualities that characterize these "transformable" cells? We have isolated mutants that affect the efficiency of transformation by the LiAc/ssDNA/ PEG method. Analysis of these mutants will allow the identification and characterization of genes involved in the transformation process and should elucidate the mechanisms of DNA uptake and establishment.

\section{REFERENCES}

1.Agatep, R., R.D. Kirkpatrick, D.L. Parchaliuk, R.A. Woods, and R.D. Gietz. 1998. Transformation of Saccharomyces cerevisiae by the lithium acetate/single-stranded carrier DNA/polyethylene glycol (LiAc/SS-DNA/ PEG) protocol. Technical Tips OnLine 1:51:P01525.

2.Armaleo, D., G.N. Ye, T.M. Klein, K.B. Shark, J.C. Sanford, and S.A. Johnston. 1990. Biolistic nuclear transformation of Saccharomyces cerevisiae and other fungi. Curr. Genet. 17:97-103.

3.Avery, O.T., C.M. MacLeod, and M. McCarty. 1944. Studies on the chemical nature of the substance inducing transformation of pneumococcal types. J. Exp. Med. 79:137157.

4.Baker, R. 1991. Rapid colony transformation of Saccharomyces cerevisiae. Nucleic Acids Res. 19:1945.

5.Barre, F.X., L.M. Mir, Y. Lecluse, and A. Harel-Bellan. 1998. Highly efficient oligonucleotide transfer into intact yeast cells using square-wave pulse electroporation. BioTechniques 25:294-296.

6.Bartel, P.L. and S. Fields. 1995. Analyzing protein-protein interactions using two-hybrid system. Methods Enzymol. 254:241-263.

7.Basabe, L., N. Cabrera, V. Yong, J. Menendez, J.M. Delgado, and L. Rodriguez. 1996. Isolation and characterization of mutants as an approach to a transformation system in Kluyveromyces marxianus. Curr. Genet. 30:89-92.

8.Bates, G.W. 1995. Electroporation of plant protoplasts and tissues. Methods Cell Biol. 50:363-373.

9.Beach, D., M. Piper, and P. Nurse. 1982. Construction of a Schizosaccharomyces pombe gene bank in a yeast bacterial shuttle vector and its use to isolate genes by complementation. Mol. Gen. Genet. 187:326-329.

10.Becker, D.M. and L. Guarente. 1991. Highefficiency transformation of yeast by electroporation. Methods Enzymol. 194:182-187.

11.Beggs, J.D. 1978. Transformation of yeast by a replicating hybrid plasmid. Nature 275:104109.

12.Broach, J.R., J.N. Strathern, and J.B. Hicks. 1979. Transformation in yeast: development of a hybrid cloning vector and isolation of the CAN1 gene. Gene 8:121-133.

13.Broker, M. 1987. Transformation of intact Schizosaccharomyces pombe cells with plasmid DNA. BioTechniques 5:516-518.

14.Bruschi, C.V., A.R. Comer, and G.A. Howe. 1987. Specificity of DNA uptake during whole cell transformation of $S$. cerevisiae. Yeast 3:131-137.

15.Brzobohaty, B. and L. Kovac. 1986. Factors enhancing genetic transformation of intact yeast cells modify cell wall porosity. J. Gen. Microbiol. 132:3089-3093.

16.Burgers, P.M.J. and L.J. Percival. 1987. Transformation of yeast spheroplasts without cell fusion. Anal. Biochem. 163:391-397.

17.Burke, D.T., G.F. Carle, and M.V. Olson. 1987. Cloning of large segments of exogenous DNA into yeast by means of artificial chromosome vectors. Science 236:806-812.

18.Calvin, N.M. and P.C. Hanawalt. 1988. High-efficiency transformation of bacterial cells by electroporation. J. Bacteriol. 170:2796-2801.

19. Cantell, C. and E. Lai. 1993. Alginate as ma- 
trix support for yeast artificial chromosome cloning. Methods Enzymol. 217:431-436.

20.Chang, A.C.Y., R.A. Lansman, D.A. Clayton, and S.N. Cohen. 1975. Studies of mouse mitochondrial DNA in Escherichia coli: structure and function of the eukaryotic-procaryotic chimera plasmids. Cell 6:231-244.

21.Chen, D.C., J.M. Beckerich, and C. Gaillardin. 1997. One-step transformation of the dimorphic yeast Yarrowia lipolytica. Appl. Microbiol. Biotechnol. 48:232-235.

22.Chen, D.C., B.C. Yang, and T.T. Kuo. 1992 One-step transformation of yeast in stationary phase. Curr. Genet. 21:83-84.

23.Chu, G., H. Hayakawa, and P. Berg. 1987. Electroporation for the efficient transfection of mammalian cells with DNA. Nucleic Acids Res. 15:1311-1326.

24. Chua, G., L. Taricani, W. Stangle, and P.G. Young. 2000. Insertional mutagenesis based on illegitimate recombination in Schizosaccharomyces pombe. Nucleic Acids Res. 28:E53 i-E53 vi.

25. Clarke, L. and J. Carbon. 1980. Isolation of a yeast centromere and construction of functional small circular chromosomes. Nature 287:504-509.

26.Costaglioli, P., E. Meilhoc, and J.M. Masson. 1994. High-efficiency electrotransformation of the yeast Schwanniomyces occidentalis. Curr. Genet. 27:26-30.

27.Costanzo, M.C. and T.D. Fox. 1988. Transformation of yeast by agitation with glass beads. Genetics 120:667-670.

28.Cregg, J.M., K.J. Barringer, A.Y. Hessler, and K.R. Madden. 1985. Pichia pastoris as a host system for transformations. Mol. Cell Biol. 5:3376-3385.

29.Cregg, J.M. and K.A. Russell. 1998. Transformation. Methods Mol. Biol. 103:27-39.

30.Das, S., E. Kellermann, and C.P. Hollenberg. 1984. Transformation of Kluyveromyces fragilis. J. Bacteriol. 158:1165-1167.

31.De Backer, M.D., D. Maes, S. Vandoninck, M. Logghe, R. Contreras, and W.H. Luyten. 1999. Transformation of Candida albicans by electroporation. Yeast 15:1609-1618

32.De Nobel, J.G. and J.A. Barnett. 1991. Passage of molecules through yeast cell walls: a brief essay-review. Yeast 7:313-323.

33.Delorme, E. 1989. Transformation of Saccharomyces cerevisiae by electroporation. Appl. Environ. Microbiol. 55:2242-2246.

34.Dohmen, R.J., A.W. Strasser, C.B. Honer, and C.P. Hollenberg. 1991. An efficient transformation procedure enabling long-term storage of competent cells of various yeast genera. Yeast 7:691-692.

35.Eddy, A.A. and D.H. Williamson. 1957. A method of isolating protoplasts from yeast. Nature 179:1252-1253.

36.Elble, R. 1992. A simple and efficient procedure for transformation of yeasts. BioTechniques 13:18-20.

37.Fincham, J.R. 1989. Transformation in fungi [published erratum appears in Microbiol. Rev 55:334]. Microbiol. Rev. 53:148-170.

38.Fox, A.S., W.F. Duggleby, W.M. Gelbart, and S.B. Yoon. 1970. DNA-Induced transformation in Drosophila: evidence for transmission without integration. Proc. Natl. Acad. Sci. USA 67:1834-1838.
39.Ganeva, V., B. Galutzov, and J. Teissie. 1995. Electric field mediated loading of macromolecules in intact yeast cells is critically controlled at the wall level. Biochim. Biophys. Acta 1240:229-236.

40.Ganeva, V., B. Galutzov, and J. Teissie. 1995. Fast kinetic studies of plasmid DNA transfer in intact yeast cells mediated by electropulsation. Biochem. Biophys. Res. Com mun. 214:825-832.

41.Gietz, D., A. St. Jean, R.A. Woods, and R.H. Schiestl. 1992. Improved method for high efficiency transformation of intact yeast cells. Nucleic Acids Res. 20:1425.

42.Gietz, R.D. and R.H. Schiestl. 1991. Applications of high efficiency lithium acetate transformation of intact yeast cells using single-stranded nucleic acids as carrier. Yeast 7:253-263.

43.Gietz, R.D., R.H. Schiestl, A.R. Willems, and R.A. Woods. 1995. Studies on the transformation of intact yeast cells by the LiAc/SS-DNA/PEG procedure. Yeast 1 1:355-360.

44.Gietz, R.D. and A. Sugino. 1988. New yeastEscherichia coli shuttle vectors constructed with in vitro mutagenized yeast genes lacking six-base pair restriction sites. Gene 74:527534.

45.Gietz, R.D., B. Triggs-Raine, A. Robbins, K.C. Graham, and R.A. Woods. 1997. Identification of proteins that interact with a protein of interest: applications of the yeast twohybrid system. Mol. Cell Biochem. 172:67-79.

46.Gietz, R.D. and R.A. Woods. 1994. High efficiency transformation with lithium acetate, p. 121-134. In J.R. Johnston (Ed.), Molecular Genetics of Yeast: A Practical Approach. Oxford University Press, Oxford.

47.Gietz, R.D. and R.A. Woods. 1998. Transformation of yeast by the lithium acetate/single stranded carrier DNA/PEG method, p. 5366. In A.J.P. Brown and M.F. Tuite (Eds.), Methods in Microbiology, Volume 26. Yeast Gene Analysis. Academic Press, San Diego.

48.Gleeson, M.A., G.S. Ortori, and P.E. Sudbery. 1986. Transformation of the methylotrophic yeast Hansenula polymorpha. J. Gen. Microbiol. 132:3459-3465.

49.Grey, M. and M. Brendel. 1992. A tenminute protocol for transforming Saccharomyces cerevisiae by electroporation. Curr. Genet. 22:335-336.

50.Griffith, F. 1928. The significance of pneumococcal types. J. Hyg. (London) 27:113159

51.Gyuris, J. and E.G. Duda. 1986. High-efficiency transformation of Saccharomyces cerevisiae cells by bacterial minicell protoplast fusion. Mol. Cell Biol. 6:3295-3297.

52.Harashima, S., A. Takagi, and Y. Oshima. 1984. Transformation of protoplasted yeast cells is directly associated with cell fusion. Mol. Cell Biol. 4:771-778.

53.Harris, G. and C.C. Thompson. 1960. Alleged transformation of yeast. Nature 188 : 1212-1213.

54.Hashimoto, H., H. Morikawa, K. Yamada, and A. Kimura. 1985. A novel method for transformation of intact yeast cells by electroinjection of plasmid DNA. Appl. Microbi- ol. Biotechnol. 21:336-339

55.Heiser, W.C. 2000. Optimizing electroporation conditions for the transformation of mammalian cells. Methods Mol. Biol. 130:117-134.

56.Hill, D.E. 1989. Integrative transformation of yeast using electroporation. Nucleic Acids Res. 17:8011.

57.Hill, J., K.A. Ian, G. Donald, and D.E. Griffiths. 1991. DMSO-enhanced whole cell yeast transformation. Nucleic Acids Res. 19:5791.

58.Hinnen, A., J.B. Hicks, and G.R. Fink. 1978. Transformation of yeast. Proc. Natl. Acad. Sci. USA 75:1929-1933.

59.Hood, M.T. and C. Stachow. 1990. Transformation of Schizosaccharomyces pombe by electroporation. Nucleic Acids Res. 18:688.

60.Hutchison, H.T. and L.H. Hartwell. 1967. Macromolecule synthesis in yeast spheroplasts. J. Bacteriol. 94:1697-1705.

61.Iborra, F. 1993. High efficiency transformation of Kluyveromyces marxianus by a replicative plasmid. Curr. Genet. 24:181-183.

62.Iimura, Y., K. Gotoh, K. Ouchi, and T. Nishiya. 1983. Yeast transformation without the spheroplasting process. Agric. Biol. Chem. 47:897-901.

63.Ito, H., Y. Fukuda, K. Murata, and A. Kimura. 1983. Transformation of intact yeast cells treated with alkali cations. J. Bacteriol. 153:163-168.

64.Ito, H., K. Murata, and A. Kimura. 1983. Transformation of yeast cells treated with 2 mercaptoethanol. Agric. Biol. Chem. 47: 1691-1692.

65.Johnston, J., F. Hilger, and R. Mortimer. 1981. Variation in frequency of transformation by plasmid YRp7 in Saccharomyces cerevisiae. Gene 16:325-329.

66.Johnston, S.A., P.Q. Anziano, K. Shark, J.C. Sanford, and R.A. Butow. 1988. Mitochondrial transformation in yeast by bom bardment with microprojectiles. Science 240:1538-1541.

67.Johnston, S.A. and M.J. DeVit. 1996. Biolistic transformation of yeasts. Methods Mol. Biol. 53:147-153.

68.Kao, K.N. and M.R. Michayluk. 1974. A method for high-frequency intergeneric fusion of plant protoplasts. Planta 115:355-367.

69.Karube, I., E. Tamiya, and J. Matsuoka. 1985. Transformation of Saccharomyces cerevisiae spheroplasts by high electric pulse. FEBS Lett. 182:90-94.

70.Kasuske, A., H. Wedler, S. Schulze, and D. Becher. 1992. Efficient electropulse transformation of intact Candida maltosa cells by different homologous vector plasmids. Yeast 8:691-697.

71.Kedes, L.H., A.C.Y. Chang, D. Houseman, and S.N. Cohen. 1975. Isolation of histone genes from unfractioned sea urchin DNA by subculture cloning in E. coli. Nature 255:533538

72.Keszenman-Pereyra, D. and K. Hieda. 1988. A colony procedure for transformation of Saccharomyces cerevisiae. Curr. Genet. 13:21-23.

73.Khan, N.C. and S.P. Sen. 1974. Genetic transformation in yeasts. J. Gen. Microbiol $83: 237-250$ 
74.Kimura, A., A. Arima, and K. Murata. 1981. Biofunctional change in yeast cell surface on treatment with Triton X-100. Agric. Biol. Chem. 45:2627.

75.Klebe, R.J., J.V. Harriss, Z.D. Sharp, and M.G. Douglas. 1983. A general method for polyethylene-glycol-induced genetic transformation of bacteria and yeast. Gene 25:333341.

76.Klein, R.D. and M.A. Favreau. 1988. Transformation of Schwanniomyces occidentalis with an $A D E 2$ gene cloned from $S$. occidentalis. J. Bacteriol. 170:5572-5578.

77.Klein, T.M., E.D. Wolf, R. Wu, and J.C. Sanford. 1987. High-velocity microprojectiles for delivering nucleic acids into living cells. Nature 327:70-73.

78.Lauermann, V. 1991. Ethanol improves the transformation efficiency of intact yeast cells. Curr. Genet. 20:1-3

79.Lindquist S. and E.A. Craig. 1988. The heat-shock proteins. Annu. Rev. Genet. 22:631-677.

80.Linske-O'Connell, L.I., F. Sherman, and G. McLendon. 1995. Stabilizing amino acid replacements at position 52 in yeast iso-1-cytochrome c: in vivo and in vitro effects. Biochemistry 34:7094-7102.

81.Manivasakam, P. and R.H. Schiestl. 1993 High efficiency transformation of Saccharomyces cerevisiae by electroporation [published erratum appears in Nucleic Acids Res. 11:4856]. Nucleic Acids Res. 21:4414-4415.

82.Meilhoc, E., J.M. Masson, and J. Teissie. 1990. High efficiency transformation of intact yeast cells by electric field pulses [published erratum appears in Biotechnology (NY) 8:768]. Biotechnology (NY) 8:223-227.

83.Miller, J.F., W.J. Dower, and L.S. Tompkins. 1988. High-voltage electroporation of bacteria: genetic transformation of Campylobacter jejuni with plasmid DNA. Proc. Natl. Acad. Sci. USA 85:856-860.

84.Mishra, N.C. and E.L. Tatum. 1973. Nonmendelian inheritance of DNA-induced inositol independence in Neurospora. Proc. Natl. Acad. Sci. USA 70:3875-3879.

85.Moerschell, R.P., G. Das, and F. Sherman. 1991. Transformation of yeast directly with synthetic oligonucleotides. Methods Enzymol. 194:362-369.

86.Moreno, S., A. Klar, and P. Nurse. 1991. Molecular genetic analysis of the fission yeast Schizosaccharomyces pombe. Methods Enzymol. 194:795-823.

87.Morrow, J.F., S.N. Cohen, A.C.Y. Chang, H.W. Boyer, H.M. Goodman, and R.B. Helling. 1974. Replication and transcription of eukaryotic DNA in Escherichia coli. Proc. Natl. Acad. Sci. USA 71:1743-1747.

88.Murray, A.W. and J.W. Szostak. 1983. Construction of artificial chromosomes in yeast. Nature 305:189-193.

89.Neumann, E., S. Kakorin, I. Tsoneva, B. Nikolova, and T. Tomov. 1996. Calcium-mediated DNA adsorption to yeast cells and kinetics of cell transformation by electroporation. Biophys. J. 71:868-877.

90.Neumann, E., M. Schaefer-Ridder, Y. Wang, and P.H. Hofschneider. 1982. Gene transfer into mouse lyoma cells by electroporation in high electric fields. EMBO J. 1:841-
845.

91.Okazaki, K., N. Okazaki, K. Kume, S. Jinno, K. Tanaka, and H. Okayama. 1990. High-frequency transformation method and library transducing vectors for cloning mam malian cDNAs by trans-complementation of Schizosaccharomyces pombe. Nucleic Acids Res. 18:6485-6489.

92.Oppenoorth, W.F.F. 1960. J. Microbiol. Serol. 26:129.

93.Parent, S.A., C.M. Fenimore, and K.A. Bostian. 1985. Vector systems for the expression, analysis and cloning of DNA sequences in S. cerevisiae. Yeast 1:83-138.

94.Piredda, S. and C. Gaillardin. 1994. Development of a transformation system for the yeast Yamadazyma (Pichia) ohmeri. Yeast 10:1601-1612.

95.Potter, H. 1993. Application of electroporation in recombinant DNA technology. Methods Enzymol. 217:461-478.

96.Potter, H., L. Weir, and P. Leder. 1984. Enhancer-dependent expression of human kappa immunoglobulin genes introduced into mouse pre-B lymphocytes by electroporation. Proc. Natl. Acad. Sci. USA 81:7161-7165.

97.Prentice, H.L. 1992. High efficiency transformation of Schizosaccharomyces pombe by electroporation. Nucleic Acids Res. 20:621.

98. Ratzkin, B. and J. Carbon. 1977. Functional expression of cloned yeast DNA in Escherichia coli. Proc. Natl. Acad. Sci. USA 74:487-491.

99.Raymond, C.K., V.R. Mugford, and S.L. Sexson. 1999. Plasmid topologies that enhance the transformation efficiency of yeast. BioTechniques 27:892-4, 896

100.Rech, E.L., M.J. Dobson, M.R. Davey, and B.J. Mulligan. 1990. Introduction of a yeast artificial chromosome vector into Saccharomyces cerevisiae cells by electroporation. Nucleic Acids Res. 18:1313.

101.Reddy, A. and F. Maley. 1993. Dithiothreitol improves the efficiency of yeast transformation. Anal. Biochem. 208:211-212.

102.Roggenkamp, R., H. Hansen, M. Eckart, Z. Janowicz, and C.P. Hollenberg. 1986. Transformation of the methylotrophic yeast Hansenula polymorpha by autonomous replication and integration vectors. Mol. Gen. Genet. 202:302-308.

103.Rose, M.D. 1987. Isolation of genes by com plementation in yeast. Methods Enzymol. 152:481-504.

104.Rosenfeld, S.A. 1999. Use of Pichia pastoris for expression of recombinant proteins. Methods Enzymol. 306:154-169.

105.Sanglard, D., F. Ischer, M. Monod, and J. Bille. 1996. Susceptibilities of Candida albicans multidrug transporter mutants to various antifungal agents and other metabolic inhibitors. Antimicrob. Agents Chemother. 40:2300-2305.

106.Schiestl, R.H. and R.D. Gietz. 1989. High efficiency transformation of intact yeast cells using single stranded nucleic acids as a carrier. Curr. Genet. 16:339-346.

107.Schiestl, R.H., P. Manivasakam, R.A. Woods, and R.D. Gietz. 1993. Introducing DNA into yeast by transformation. Methods 5:79-85.

108.Simon, J.R. and K. McEntee. 1989. A rapid and efficient procedure for transformation of intact Saccharomyces cerevisiae by electroporation. Biochem. Biophys. Res. Commun. 164:1157-1164.

109.Soni, R., J.P. Carmichael, and J.A. Murray. 1993. Parameters affecting lithium acetatemediated transformation of Saccharomyces cerevisiae and development of a rapid and simplified procedure. Curr. Genet. 24:455459 .

110.Spencer, F., G. Ketner, C. Connelly, and P. Hieter. 1993. Targeted recombination-based cloning and manipulation of large DNA segments in yeast. Methods 5:161-175.

111.Struhl, K., D.T. Stinchcomb, S. Scherer, and R.W. Davis. 1979. High-frequency transformation of yeast: autonomous replication of hybrid DNA molecules. Proc. Natl. Acad. Sci. USA 76:1035-1039.

112.Svoboda, A. 1966. Regeneration of yeast protoplasts in agar gels. Exp. Cell Res. 44:640-642.

113.Svoboda, A. and O. Necas. 1966. Regeneration of yeast protoplasts prepared by snail enzyme. Nature 210:845.

114.Tan, S-L., M. Dossett, and M.G. Katze. 1998. Cryopreserved yeast cells for routine, small-scale transformations. BioTechniques 25:792-796s.

115.Thompson, J.R., E. Register, J. Curotto, M. Kurtz, and R. Kelly. 1998. An improved protocol for the preparation of yeast cells for transformation by electroporation. Yeast 14:565-571.

116.Tikhomirova, L.P., R.N. Ikonomova, and E.N. Kuznetsova. 1986. Evidence for autonomous replication and stabilization of recombinant plasmids in the transformants of yeast Hansenula polymorpha. Curr. Genet. 10:741-747.

117.van Solingen, P. and J.B. van der Plaat. 1977. Fusion of yeast spheroplasts. J. Bacteriol. 130:946-947.

118.Woods, R.A. and R.D. Gietz. 2000. Yeast transformation. In P.A. Norton and L.F. Steel (Eds.), Gene Transfer Methods: Introducing DNA into Living Cells and Organisms. Eaton Publishing, Natick, MA

119.Yamakawa, M., F. Hishinuma, and N. Gunge. 1985. Intact cell transformation of Saccharomyces cerevisiae by polyethylene glycol. Agric. Biol. Chem. 49:869-871.

120. Yamamoto, T., R.P. Moerschell, L.P. Wakem, D. Ferguson, and F. Sherman. 1992. Parameters affecting the frequencies of transformation and co-transformation with synthetic oligonucleotides in yeast. Yeast $8: 935$ 948.

Received 11 September 2000; accepted 16 January 2001.

Address correspondence to:

Dr. R. Daniel Gietz

Department of Biochemistry and Medical Genetics

University of Manitoba, 770 Bannatyne Ave. Winnipeg, MB, Canada, R3M OW3

e-mail.: gietz@cc.umanitoba.ca 